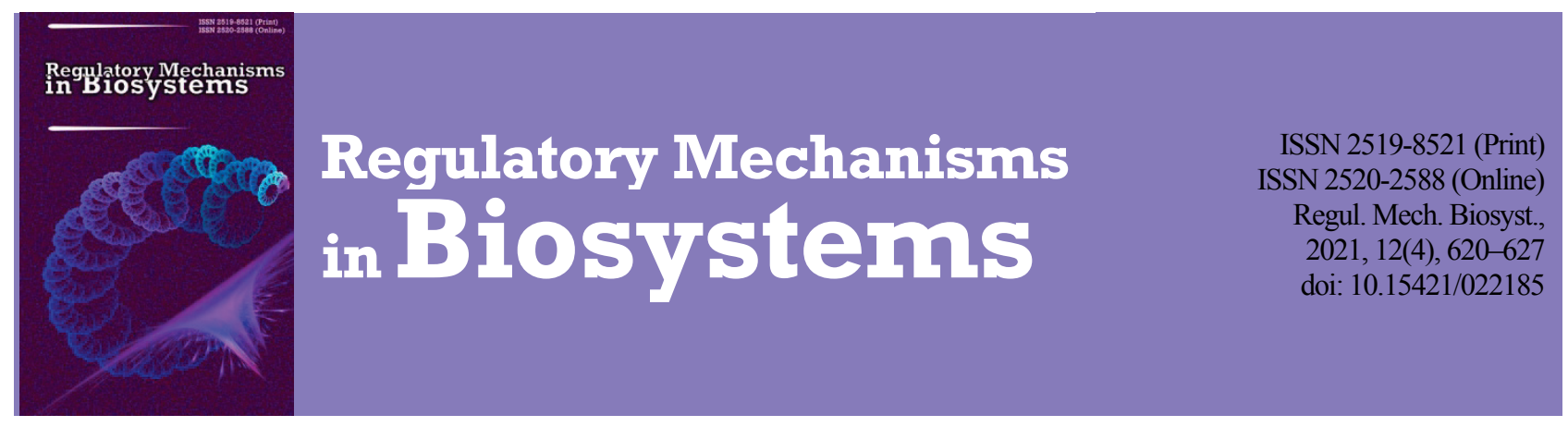

\title{
Comparative flower morphology of Agapanthus africanus and $A$. praecox (Amaryllidaceae)
}

\author{
O. S. Fishchuk \\ Lesya Ukrainka Volyn National University, Lutsk, Ukraine
}

Article info

Received 25.09.2021

Received in revised form

18.10.2021

Accepted 20.10.2021

Lesya Ukrainka

Volyn National University,

Volipr., 13,

Lutsk, 43025, Ukraine.

Tel.: +38-066-310-81-07.

E-mail:

dracaenaok@ukr.net

Fishchuk, O. S. (2021). Comparative flower morphology of Agapanthus africanus and A. praecox (Amaryllidaceae). Regulatory Mechanisms in Biosystems, 12(4), 620-627. doi:10.15421/022185

The structure of Agapanthus africanus and A. praecox flowers was studied on permanent cross-sectional and longitudinal sections using a light microscope. The genus Agapanthus belongs to the subfamily Agapanthoideae, the family Amaryllidaceae, which is characterized by the presence of the upper ovary, septal nectaries and fruit - fleshy capsule. Micromorphological studies of the flower are considered as a way for detection of unknown plant features, adjustment of plants to specialized ways of pollination and determining the first stages of morphogenesis of fruit, and further use these features in taxonomy. 10 flowers of $A$. africanus and $A$. praecox were sectioned using standard methods of Paraplast embedding and serial sectioning at 20 micron thickness. Sections were stained with Safranin and Astra Blau and mounted in Eukitt. It was found that in the studied species the tepals have single-bundle traces. The vascular system of the superior ovary consists of a three bundle dorsal vein, of the ventral roots complex, which are reorganized into paired ventral bundles of the carpel, which form traces to ovules. For the first time, the following gynoecium zones were detected in A. africanus: a synascidiate structural zone with a height of about $560 \mu \mathrm{m}$ and a fertile symplicate structural zone with a height of about $380 \mu \mathrm{m}$ and a hemisymplicate zone of $2580 \mu \mathrm{m}$. In $A$. praecox gynoecium, there is a synascidiate structural zone with a height of $200 \mu \mathrm{m}$ and a symplicate structural zone of $600 \mu \mathrm{m}$ and a hemisymplicate zone of $620 \mu \mathrm{m}$. Septal nectaries appear in the hemisymplicate zone and open with nectar fissures at the base of the column, with a total septal nectar height of $2880 \mu \mathrm{m}$ in A. africanus and $820 \mu \mathrm{m}$ in A. praecox. The ovary roof is $300 \mu \mathrm{m}$ in A. africanus and $200 \mu \mathrm{m}$ in A. praecox. Triple dorsal bundles of carpels in A. africanus have been identified, which could be considered as adaptation of different stages of morphogenesis of fruit to dehiscence. The new data obtained by the vascular anatomy of the flower and the presence of different ovary zones significantly add to the information about anatomical and morphological features of the studied species, which can be further used in the taxonomy of the family Amaryllidaceae.

Keywords: Agapanthoideae; ovary; flower morphology; gynoecium; septal nectary.

\section{Introduction}

Molecular-phylogenetic analysis allows the division of genera, subfamilies and families, by molecular characteristics, but scientists do not always take into account such important features of flower structure as features of vascular anatomy and structure of septal nectaries, the presence and height of ovarian zones, although the basis for taxonomic systems may also be signs of flower micromorphology. The integration of data from molecular phylogenetics and evolutionary comparative flower morphology is a promising direction for the construction of modern evolutionary taxonomy. The study of micromorphology and vascular anatomy of monocotyledonous flowers and fruits is a modern direction in the study of evolutionary morphology (Odintsova \& Fishchuk, 2017; Skrypec \& Odintsova, 2020). Molecular-phylogenetic reconstructions of the subfamily Agapanthaceae have been carried out by many scientists Pires et al. (2006), Seberg et al. (2012), Chase et al. (2016).

The objects of our study were Agapanthus africanus (L.) Hoffmanns and A. praecox Willd. They belong to the genus Agapanthus, subfamily Agapanthoideae, family Amaryllidaceae (Chase et al., 2009; Chase et al., 2016). The genus belongs to the subfamily Agapanthoideae and has been the subject of debate since its inception. In the Cronquist system, the genus was placed in a very broad family Liliaceae along with other lilioid monocotyledonous plants (Cronquist, 1981). In 1985, R. Dahlgren, H. Clifford, and P. Yeo placed Agapanthus in the family Alliaceae, closer to the genus Tulbaghia (Dahlgren et al., 1985). According to them, the family Alliaceae also included several genera, which would later be transferred to the family Themidaceae. In 1996, after phylogenetic analysis of the DNA sequences of the rbcL gene, Themidaceae was returned and Agapanthus was removed from Alliaceae (Fay \& Chase, 1996). The authors found that Agapanthus is a sister clade to the subfamily Amaryllidaceae and moved it to this family. The Angiosperm Phylogeny Group (APG, 1998) disagreed with this distribution when they published the APG system in 1998, as the Agapanthus and Amaryllidaceae clade had only 63\% support. The APG system identified three separate families: Agapanthaceae, Alliaceae sensu stricto and Amaryllidaceae sensu stricto. The family Agapanthaceae included only the genus Agapanthus.

The second version of APG II (APG, 3003) was introduced to the world in 2003, it offered the possibility of combining Agapanthaceae, Alliaceae sensu stricto and Amaryllidaceae sensu stricto, under the common name Alliaceae sensu lato. Alliaceae sensu lato was later replaced by Amaryllidaceae for a broader understanding of the family, but the description of the family remained unchanged. When APG II was replaced by APG III in 2009, Agapanthaceae wasn't moved, but was considered a subfamily of Agapanthoideae with a broad understanding of the Amaryllidaceae family (APG, 2009). Takhtadjian (2009) refers the genus Agapanthus to the order Amaryllidales and the family Agapanthaceae, which includes one genus and 9 species. The order includes the three smaller families allowed by APG II, instead of combining them as in APG III (Takhtajan, 2009). Subsequent molecular phylogenetic analysis of DNA sequences confirmed that Agapanthus is a sister clade to the subfamily Allioideae and Amaryllidoideae, family Amaryllidaceae (Pires et al., 2006; Seberg et al., 2012; Chase et al., 2016). Genus Agapanthus L'Her. 
has about 9 species of herbaceous bulbous perennials that are distributed in South Africa from the Cape Peninsula to the south of the Limpopo River (Takhtajan, 2009). Characteristic features of the genus are fleshy roots, provided with a multiple velamen. Laticifers are present in genus Agapanthus. Vessels are only in roots, mostly with scalariform perforations. Calcium oxalate raphides are present in the cells (Takhtajan, 2009) and the ovary is superior, inner septal nectaries present, stigma is small, fruit is a loculicidal capsule with many flat, black, winged seeds (Meerow \& Snijman, 1998).

The study of the genus Agapanthus is relevant: assessment of fertility in horticultural selections of the genus Agapanthus (Dawson et al., 2018), dehydrins from A. praecox as protectors to improve plant cell viability during cryopreservation (Zhang et al., 2021), single-wall carbon nanotubes which improve cell survival rate and reduce oxidative injury in cryopreservation of $A$. praecox embryogenic callus (Ren et al., 2020), in vitro micropropagation of A. praecox (Baskaran \& Staden, 2013) and micropropagation of Agapanthus umbellatus var. minor (Fogaça et al., 2016), voltage production in a plant-microbial fuel cell using A. africanus (Gómora-Hernández et al., 2019). A chromosome study in Agapanthus and the phylogeny of its species was performed (Sharma \& Mukhopadhyay, 1963). Phytoecdysteroids in the genus Agapanthus have been studied (Savchenko et al., 1997). Antifungal activity of A. africanus extractives was performed by Indian scientists (Singh et al., 2020).

The history, taxonomy, distribution and cultivation requirements of the South African $A$. africanus (L.) Hoffmanns. were investigated by Duncan (2004). Micromorphological characterization of the leaf and rhizome of A. praecox subsp. praecox Willd. have been studied by Sharaibim \& Afolayan (2017). There have also been studies of fertilization and embryogeny in A.praecox ssp. orientalis (Zhang et al., 2011), flower development and senescence-related changes in A. africanus (Gören Sağlam et al., 2011), flower development and anatomy of $A$. praecox ssp. orientalis (Zhang et al., 2011), anticholinesterase and mutagenic evaluation of in vitro-regenerated A. praecox grown ex vitro (Baskaran et al., 2014), gibberellin and auxin signals control scape cell elongation and proliferation in A. praecox ssp. orientalis (Yue et al., 2016).

Therefore, the issues of taxonomy and in vitro micropropagation, fertilization, embryogeny and flower development of the genus Agapanthus have attracted considerable attention from modern researchers, but the issues of vascular anatomy of the flower, the gynoecium structure remain poorly studied. The aim of our study is to elucidate the flower morphology features and the internal structure of the gynoecium and identify its vertical zonality in members of the family Amaryllidaceae for further using them in the taxonomy of the family.

\section{Material and methods}

Ten $A$. africanus and A. praecox flower buds were collected in the agricultural station of Lesya Ukrainka Volyn National University and fixed in $70 \%$ alcohol. Flower buds were dehydrated in t-butanol series $(20 \%, 30 \%, 50 \%, 70 \%, 100 \%-2 \mathrm{~h}$ each, the last one $24 \mathrm{~h})$ and stored in $100 \% \mathrm{t}$-butanol and paraplast in the ratio $1: 1$. Infiltration was performed in Paraplast $\left(\right.$ Merck $\left.^{\mathbb{R}}\right)$ according to the described method (Barykina et al., 2004). Transverse and longitudinal sections thickness were obtained with manual rotary microtome, the thickness of the slide is $20 \mu \mathrm{m}$ (MPS-2, USSR). Then it stained in Safranin (Sigma-Aldrich ${ }^{\circledR}$ ) and Astra Blau $\left(\right.$ Merck $\left.^{\circledR}\right)$. Slides were mounted in "Eukitt" (Sigma-Aldrich ${ }^{\mathbb{B}}$ ) and images were made with an Amscope 10MP digital camera attached to an Amscope T490B-10M(USA) microscope.

For the morphological analysis, measurements were made on at least 15 fresh A. africanus and A. praecox flowers. The concept of gynoecium vertical zonality by Leinfellner (1950) was used to analyze the gynoeciaum's internal structure. This concept considers only the congenital fusion of the carpels. The congenital multilocular synascidiate, unilocular simplicate, transitional hemisimplicate, and asymplicate zones could be formed in the syncarpous gynoecium according to this concept when carpels are grown together. In terms of incomplete fusion of carpels, only in their outer part do they form a hemisyncarpous gynoecium with hemisynascidiate, hemisimplicate, and asymplicate zones; later, this method was improved for monocots (Odintsova, 2013). According to the number of cross-sections ehe height of the zones of gynoecium was measured.

\section{Results}

The flower of $A$. africanus is up to $3.0-3.4 \mathrm{~cm}$ long, light blue in colour and has a very strong aroma. The scape is $50-77 \mathrm{~cm}$ long and $0.9 \mathrm{~cm}$ in diameter at the base and $0.7 \mathrm{~cm}$ in diameter above. The pedicel is 1.8 $2.0 \mathrm{~cm}$ long, $0.1 \mathrm{~cm}$ in diameter (Fig. 2a, b). The perigonium forms a flower tube $1.8-2.0 \mathrm{~cm}$ long and $0.40-0.45 \mathrm{~cm}$ in diameter at the base. The outer tepals are $1.8,1.8,1.9 \mathrm{~cm}$ long and $0.5,0.4,0.5 \mathrm{~cm}$ wide. The inner tepals are 1.7, 2.0, $1.8 \mathrm{~cm}$ and a width of $0.8 \mathrm{~cm}$, respectively. (Fig. 2h). The flower tube and perianth leaves in the middle have dark blue stripes (Fig. 2d, g).

External and internal stamens are directed in one direction. The stamens of the inner circle are $1.9,1.9,1.8 \mathrm{~cm}$ long and $0.075 \mathrm{~cm}$ in diameter, and the stamens of the outer circle are $2.0,1.8,1.9 \mathrm{~cm}$ long and $0.05 \mathrm{~cm}$ in diameter (Fig. 2h). Filaments are light blue (Fig. 2h). The anthers are linear, anthers on outer stamens are $0.15 \mathrm{~cm}$ long and $0.10 \mathrm{~cm}$ in diameter, anthers on inner stamens are $0.10 \mathrm{~cm}$ long and $0.05 \mathrm{~cm}$ in diameter, they are attached to the stamen filament below the middle of their height. A. africanus ovary is superior (Fig. 1a), three-loculed, elongatedoval, yellow-green, $0.8 \mathrm{~cm}$ high and $0.3 \mathrm{~cm}$ in diameter. The style is filamentous, light blue and it has a central arrangement, $2.085 \mathrm{~cm}$ in height and $0.1 \mathrm{~cm}$ in diameter (Fig. 2g, h). The style is hollow at the top (Fig. 3d). The stigma has short papillae, concave inwards $0.015 \mathrm{~cm}$ long and 0.015 $\mathrm{cm}$ in diameter. In the $A$. africanus gynoecium we distinguish the following structural zones: fertile synascidiate structural zone (Fig. 2c), height about $560 \mu \mathrm{m}$ and fertile symplicate structural zone (Fig. 2d), height of which is about $380 \mu \mathrm{m}$ and hemisymplicate zone with a height of about $2580 \mu \mathrm{m}$ (Fig. 2e). There is no asymplicate zone. Septal nectaries appear along the hemisymplicate zone and open with small nectary slits at the base of the style (Fig. 2f). The total height of the septal nectary is $2880 \mu \mathrm{m}$ (Fig. 3c). The ovary roof is 300 microns (Fig. 1a). The ovary base is 1000 $\mu \mathrm{m}$ (Fig. 1a). In the upper part of the A. africanus peduncle and in the ovary wall there are cellular inclusions - raphides (Fig. 6a, b). They are absent at the flower tube base, the free tepals tops, in the stamens, and the style.

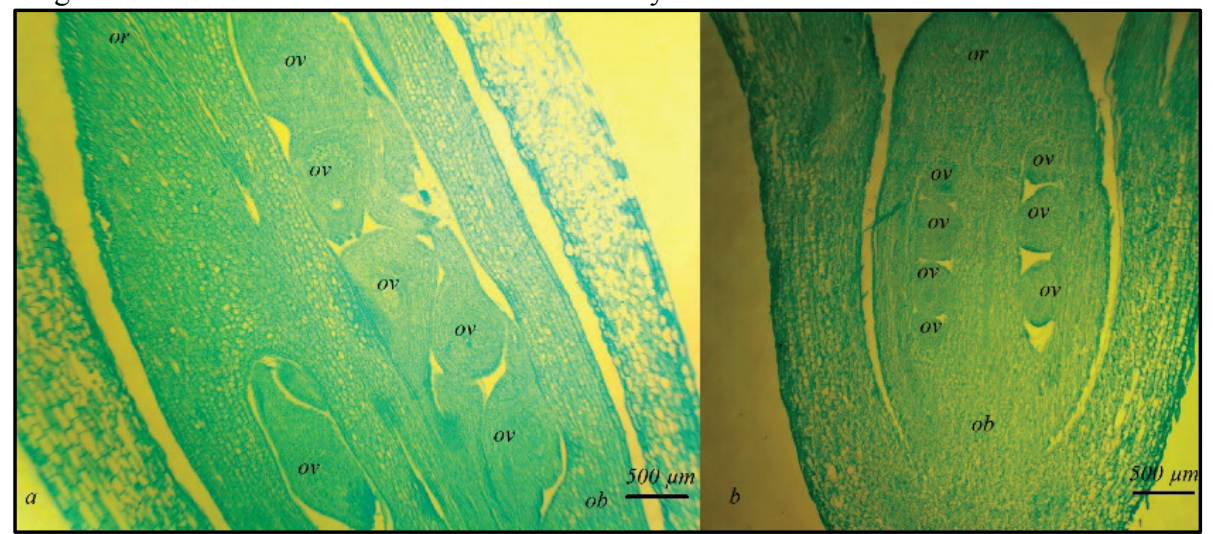

Fig. 1. Longitudinal sections of the ovary of Agapanthus africanus (a) and A.praecox (b): ov-ovule, or-ovary roof 


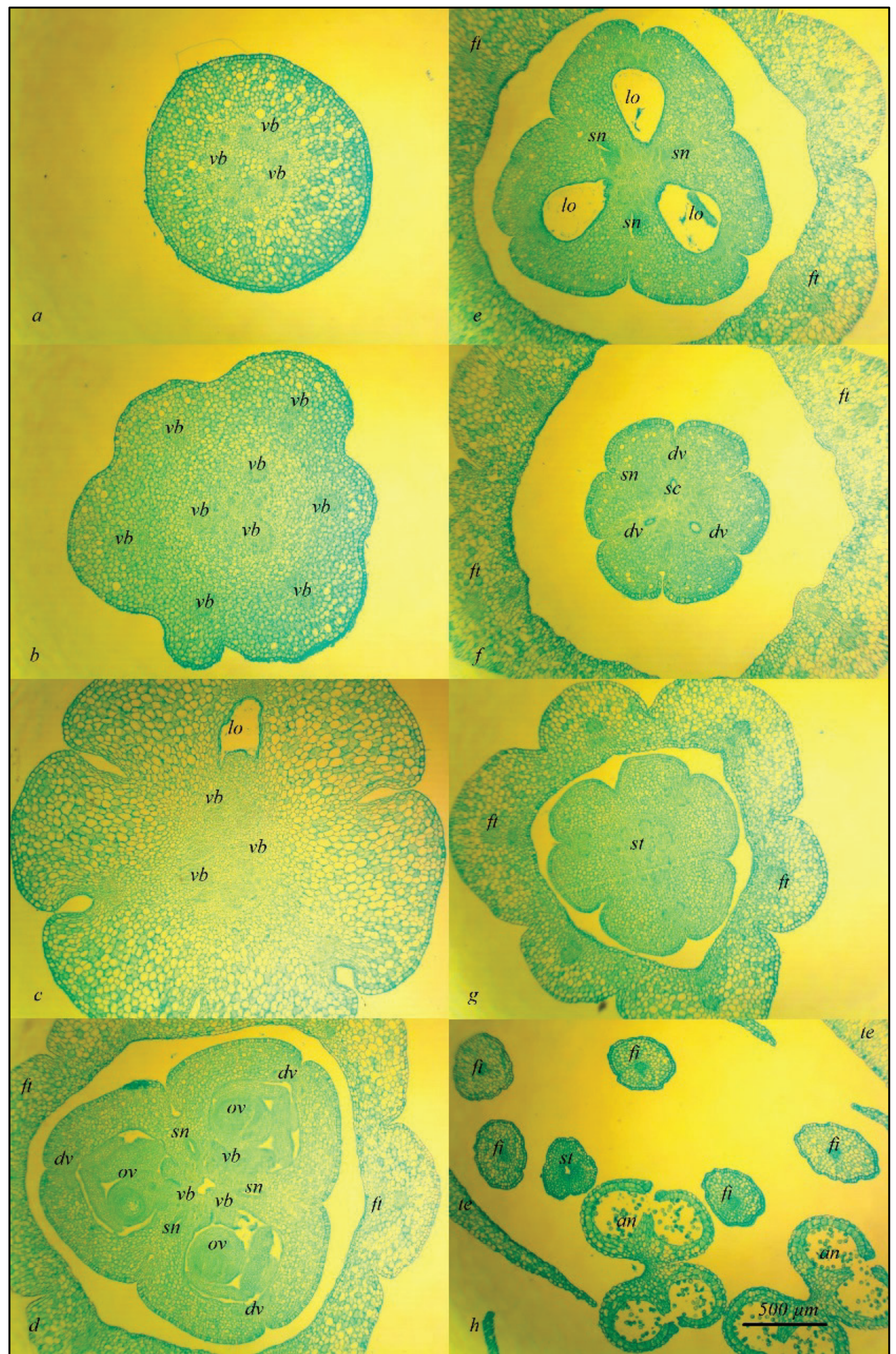

Fig. 2. Ascending series of transversal sections of the flower Agapanthus africanus: $a-b$-pedicel; $c$-synascidiate zone, $d-e-$ symplicate zone; $f$ - $g$-ovary roof, $h$-free tepals, anthers and style; $a n$ - anther; $d v$-dorsal vein; $f i$-filament; $f t$-flower tube; $l o$ - ovary locule; $o v$ - ovule; $s c$ - style channel; $s n$-septal nectaries; $s t$ - style; te-tepal; $v b$-vascular bundle 


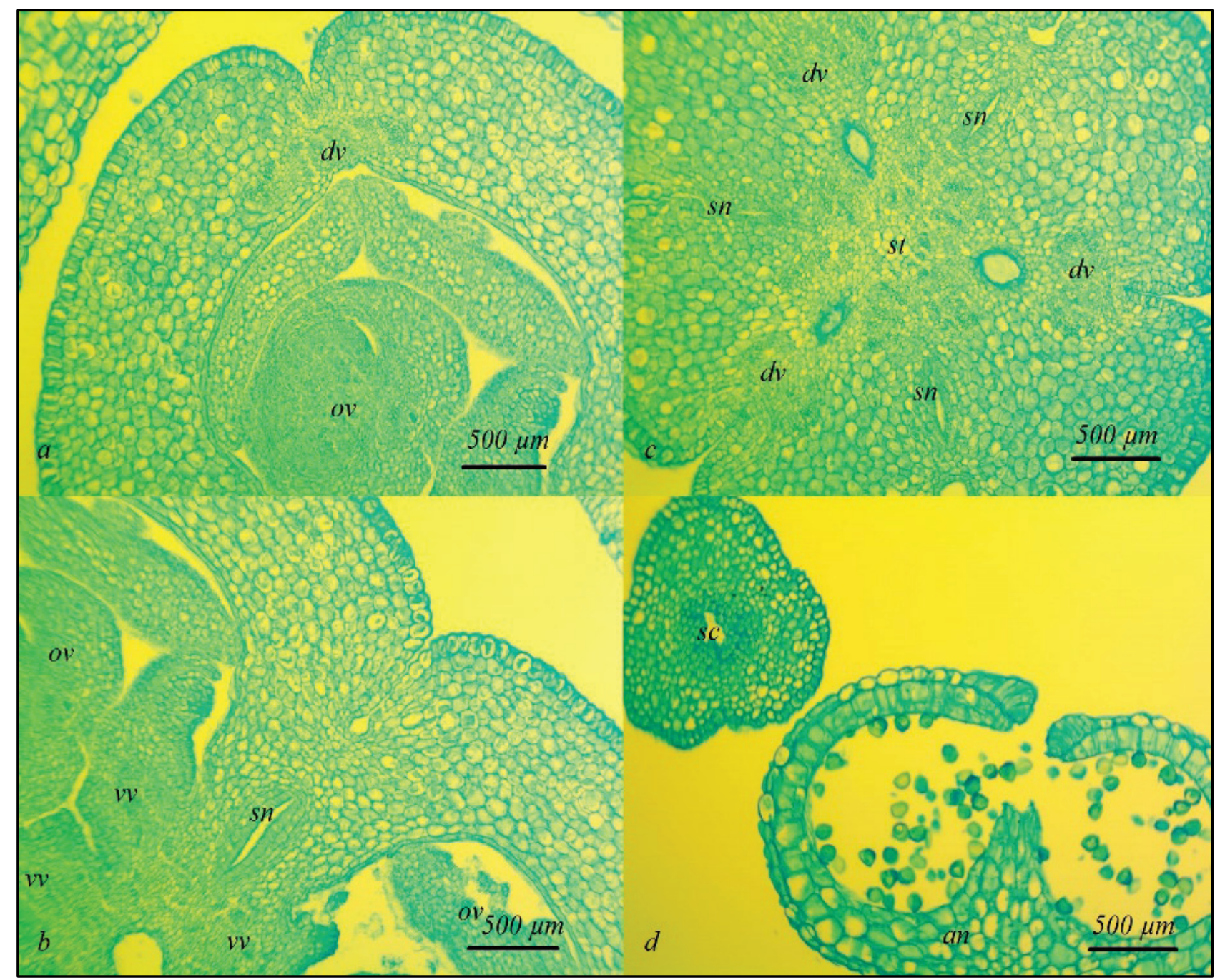

Fig. 3. Floral parts of Agapanthus africanus: $a$ - ovary wall in the median part of the carpel, dorsal vein composed of three bundles; $b$ - ovary wall with septa attached, septal nectary is visible; $c$ - central part of the ovary with septal nectaries; $d$ - style and anthers, triradial style channel is visible; $a n$ - anther; $d v$ - dorsal vein; $o v$ - ovule; $s c$ - style channel; $s n$ - septal nectaries; $s t$ - style; $v v$-ventral vein

The vascular system of the $A$. africanus peduncle consists of 10 vascular bundles (Fig. 2a), which above the level of the peduncle give rise to 12 vascular bundles, which are placed in pairs - traces of tepals and traces of stamens (Fig. 2b). In the center there are three massive bundles - dorsal vascular bundles of carpel and small vascular bundles - roots of a ventral complex (Fig. 2c), which above are reorganized into three paired vascular bundles and supplied ovules - ventral bundles of carpel (Fig. 3b). There are are 10-12 ovules in each locule (Fig. 1a), an ovule trace is singlebeam. Dorsal vascular bundles are three-bundle (Fig. 3a). Above the locules, the ventral bundles of the carpel merge with the dorsal bundles to form a dorsal vein (Fig. 2f). Traces of outer tepals and inner tepals are singlebundle (Fig. $2 \mathrm{~h}$ ). Stamens traces are single-bundle.

The A. praecox flower is up to $3.0-3.2 \mathrm{~cm}$ long, white and has a strong aroma. The scape is $92-100 \mathrm{~cm}$ long and $0.5-0.7 \mathrm{~cm}$ in diameter at the base and $0.4 \mathrm{~cm}$ in diameter above. The pedicel is $2.3-2.4 \mathrm{~cm}$ long and $0.1 \mathrm{~cm}$ in diameter (Fig. 4a, b). The perigonium is six-membered, forms a flower tube $1.1 \mathrm{~cm}$ long and $0.4-0.5 \mathrm{~cm}$ in diameter (Fig. 2c, d). The outer tepals are $2.2,2.2,2.1 \mathrm{~cm}$ long and $0.5,0.6,0.6 \mathrm{~cm}$ wide and inner tepals are 2.3, 2.3, $2.4 \mathrm{~cm}$ and a width of $0.9,0.8,0.9 \mathrm{~cm}$, respectively (Fig. $4 \mathrm{~h}$ ). The flower tube and tepals in the middle have indented stripes.

Stamens in A. praecox are grown to the perianth tube, free at the top. The filaments of the inner circle are fastened $0.5 \mathrm{~cm}$ lower than the stamens of the outer circle. The filaments of the outer circle are 2.2 $2.3 \mathrm{~cm}$ long and $0.85 \mathrm{~cm}$ in diameter, and the filaments of the outer circle are $2.4-2.6 \mathrm{~cm}$ length and $0.75 \mathrm{~cm}$ in diameter (Fig. 4g, h). Anthers are linear, on external and internal stamens anthers are $0.2 \mathrm{~cm}$ long and $0.1 \mathrm{~cm}$ in diameter and they are attached to the stamen filament below the middle of their height (Fig. 5d). A. praecox ovary is superior, three-locular, elongated-oval, green $0.7 \mathrm{~cm}$ high and $0.3 \mathrm{~cm}$ in diameter with a large number of ovules (Fig. 1b). The white style has a central arrangement $1.875 \mathrm{~cm}$ in height and $0.1 \mathrm{~cm}$ in diameter and style channels appear above the locule (Fig. 4h). The stigma have papillae $0.025 \mathrm{~cm}$ long and $0.02 \mathrm{~cm}$ in diameter.

A. praecox gynoecium has the following structural zones: fertile synascidiate structural zone (Fig. 4d), height about $200 \mu \mathrm{m}$ and fertile symplicate structural zone, height of which is about $600 \mu \mathrm{m}$ (Fig. 4e) and hemisymplicate zone with a height of about $620 \mu \mathrm{m}$ (Fig. 4f). There is no asymplicate zone. Septal nectaries appear along the hemisymplicate zone and open with nectary slits at the style base (Fig. 4g, h). The total height of the septal nectary is $820 \mu \mathrm{m}$ (Fig. 5c). The ovary roof is 200 microns (Fig. 1b). The ovary base is $600 \mu \mathrm{m}$ (Fig. 1b).

In the upper part of the $A$. praecox peduncle and in the ovary wall there are cellular inclusions - raphides (Fig. 6c, d). They are absent at the flower tube base, the free tepals tops, in the stamens, and the style.

The peduncle in A. praecox contains 8 vascular bundles (Fig. 4a), which branch above and at the level of receptacle depart 6 pairs of vascular bundles - traces of tepals and traces of stamen (Fig. 4b) s, and above traces of dorsal vascular carpel bundles (Fig. 5a).

In the center there are three massive vascular bundles - roots of a ventral complex (Fig. 5b). Above, they are transformed into paired vascular bundles - ventral bundles of the carpel (Fig. 5c). There are 6-8 ovules in each locule, the trace of the ovule is single-bundle. Dorsal vascular bundles are single-bundle (Fig. 5a). Above the ovary locule, the ventral bundles of the carpel end blindly and do not merge with the dorsal bundles. Traces of outer tepals and inner tepals are single-bundle (Fig. 5d). Stamens traces are single-bundle. 


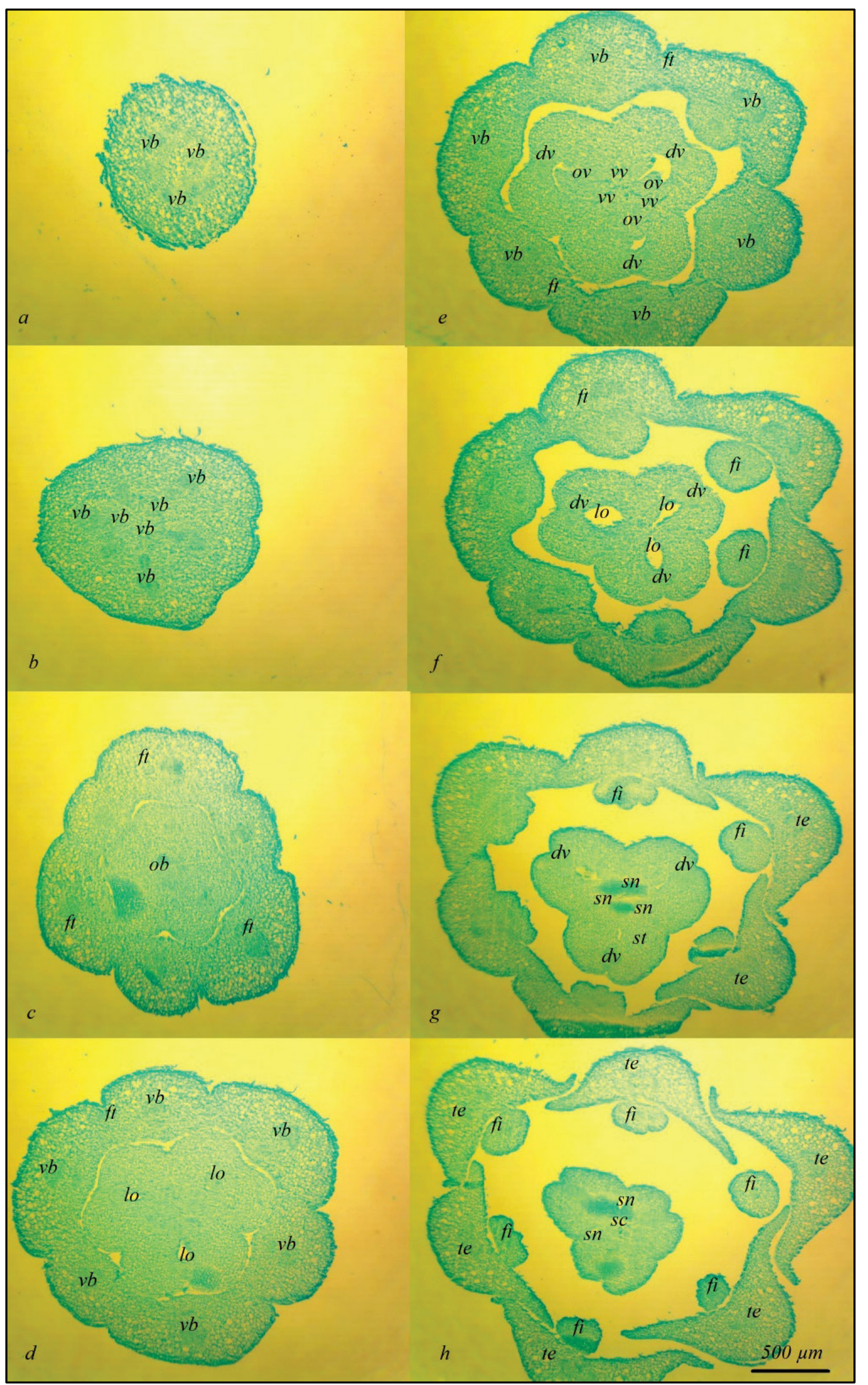

Fig. 4. Ascending series of transversal sections of the flower Agapanthus praecox: $a-b$-pedicel; $c$-inferior ovary base; $d$-synascidiate zone; $e-f$-symplicate zone; $g$ - hemisymplicate zone; $h$ - ovary roof; $d v$-dorsal vein; $f i$ - filament; $f t$ - flower tube; $l o$ - ovary locule; $o v$-ovule; $s c$ - style channel; $s n$ - septal nectaries; te - tepal; $v b$-vascular bundle; $v v$-ventral vein 


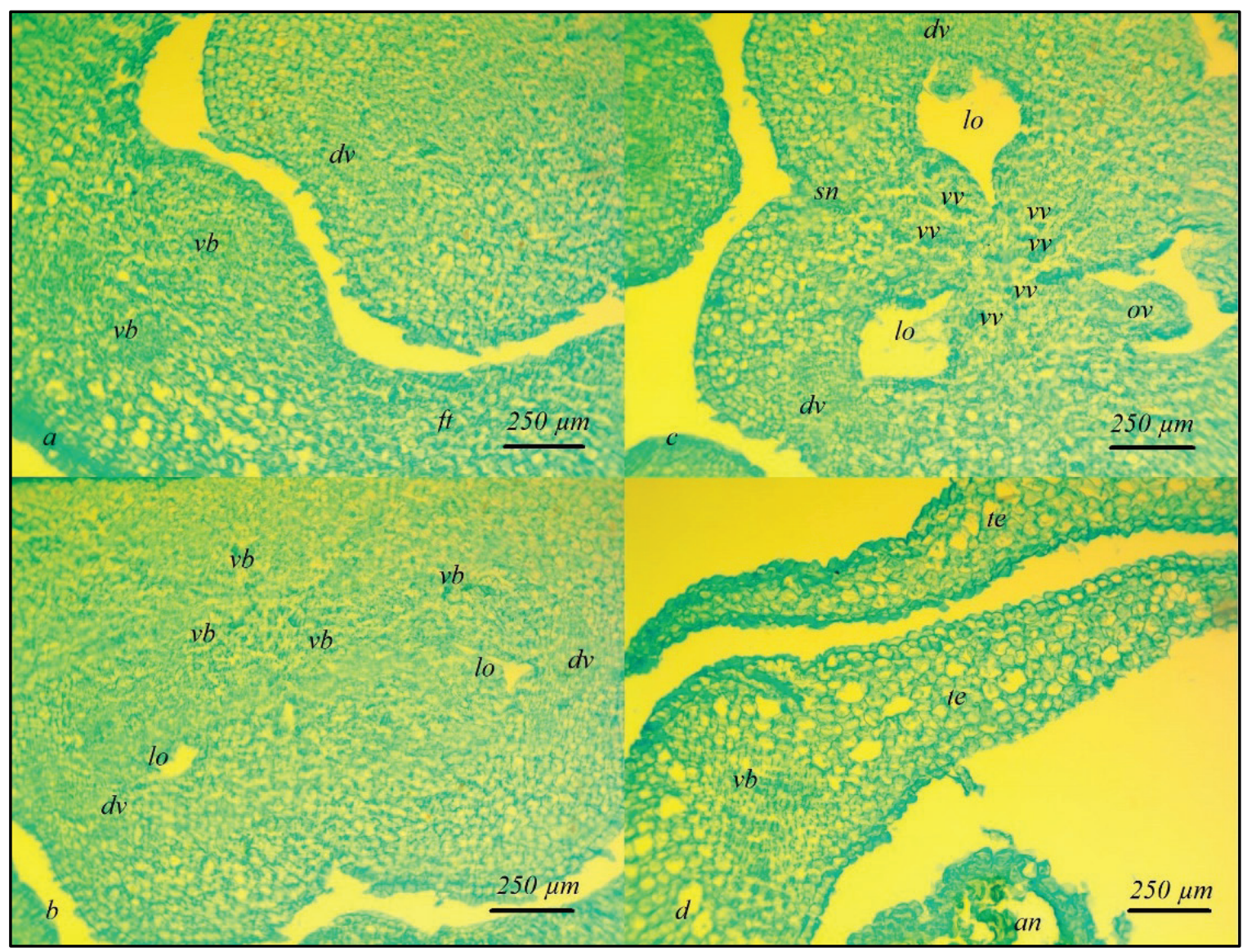

Fig. 5. Floral parts of Agapanthus praecox: $a$ - ovary wall in the median part of the carpel, dorsal vein and flower tube are visible; $b$-central part of the ovary, ovary base with locules is visible; $c$ - central part of the ovary with septal nectaries; $d$ - anther and tepals are visible; $a n$ - anther; $d v$-dorsal vein; $o v$-ovule; $s n$ - septal nectaries; te-tepal; $v b$-vascular bundle; $v v$-ventral vein

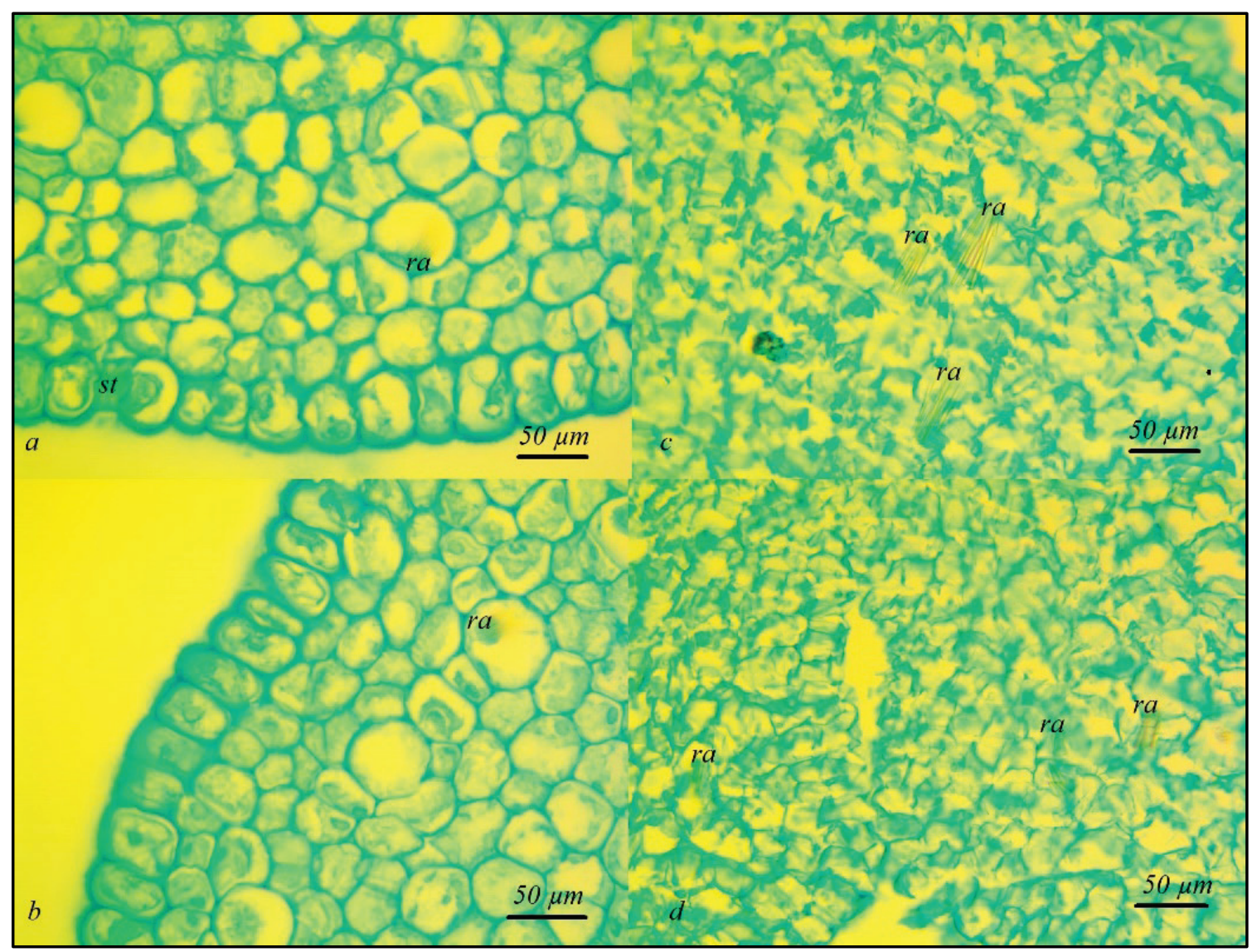

Fig. 6. Raphides and stomata in the distal parenchyma of the ovary wall of Agapanthus africanus $(a, b)$ and A. praecox $(c, d)$ : $r a$-raphides; st-stomata 


\section{Discussion}

Flowers in the genus Agapanthus are trimerous, hypogynous and zygomorphic. There are 6 tepals, basally fused, outer tepals are narrower than inner, thickened. There are 6 stamens, inserted on the tube. Filaments in genus Agapanthus are declinate, anthers are dorsifixed, introrse with longitudinal dehiscence. The ovary is always superior, ovoid and trilocular. Also in the ovary inner septal nectaries are present, there are many ovules in the ovary. The style is straight and hollow, stigma is very small. The peculiarity of the fruit is a loculicidal capsule which contains a lot of winged and black seeds (Meerow \& Snijman, 1998).

The ovary is superior in members of the genus Agapanthus. These plants are rhizomatous, roots are fleshy, provided with a multiple velamen. Vessels are only in roots, mostly with scalariform perforations. Calcium oxalate raphides are present. Leaves are rosulate, distichous, linear, sheathing at base. The flowers are in a pseudo-umbel subtended by two involucral spatial bracts, zygomorphic, pedicels subtended by threadlike bracts. Tepals are subequal, basally more or less connate. The stamens are inserted on the perianth tube; filaments are declinate, of unequal length; anthers are dorsifixed. Pollen grains are 1-colpate, reticulate. The style is slender, hollow, declinate, with punctiform stigma; ovary 3-locular, with inner septal nectaries. The ovules are numerous, campylotropous, crassinucellate. The parietal cell is present. The fruits are loculicidal capsules. The seeds are black, angulate, elongated, winged (Takhtajan, 2009).

According to Daumann (1970), the genus Agapanthus has an internal septal septal nectary. In general, the family Amaryllidaceae is characterized by the presence of septal nectaries (Daumann, 1970; Meerow \& Snijman, 1998; Takhtajan, 2009).

Most of the studied monocotyledonous nectaries have an extremely thin cuticle, only about $17 \%$ of the examined genera with septal nectar have no cuticle at the sites of nectary secretion, namely Hosta, Agapanthus, Allium. Discharge in the form of a liquid wedge passes through the sometimes more or less mucous outer walls of the epidermis and through the cuticle, without lifting or rupture during the process. There are no places on the surface of the nectary that seem best for the nectary. Isolation without the cuticle occurs in Hosta, Hemerocallis, Kniphofia, Agapanthus. The cuticle in the nectaries is absent in several cases, and only in septal nectaries in Hosta, Hemerocallis, Phormium, Kniphofia, Agapanthus, Allium, Sansevieria.

The septal nectary of $A$. umbellatus regularly contains nectar, which produces the inner septal nectary and reaches the outer groove of the septum through three discharge points at the apex of the ovary. Thus, there is only one inner septal nectary, which lines the direct septal fissures contained in the ovary from the ovary base to the ovary roof almost the entire length (i.e. except the uppermost part before the exit point), a three-layer parenchyma nectary is described in A. umbellatus (Daumann, 1970).

Changes in fresh weight, peroxidase activity, soluble protein and anthocyanin content and changes in membrane permeability at four different stages of flowering (flower bud development, anthesis, mature flowers, senescing flowers) were found in $A$. africanus. It was found that the amount of fresh weight in the stage of mature flowers is the highest when it was compared with aging flowers. There is a negative correlation between a decrease in anthocyanin content and an increase in membrane permeability in flower senescing due to the loss of semi-permeability in the membranes during senescing flowers (Gören Sağlam, 2010).

A. umbellatus L'Her is the diploid plant and no abnormality in pollen mother cells were observed. The percentage of pollen germination was $12.5-32.7 \%$. This number may be seen too small because the observation was made only one hour after pollination, and so the real number of pollen capable of germination would be higher. Two methods of pollination were used, one was cross-pollination and the other was open pollination. The results were somewhat better in the case of open pollination, namely 258 flowers were pollinated and 33 capsules were fructified, the percentage of fructified capsules for pollinated flowers were $12.8 \%$. In the case of cross-pollination 31 flowers were pollinated but no capsule was fructified. The seed of $A$. umbellatus L'Her has a crater on one side and shape of capsule is a long ellipse with high three mounds. Three kinds of seed were recognized in the capsule. The cause of high sterility in $A$. umbellatus L'Her could not be a recognized cytological relation but seemed to be in high relation with the equilibrium of nutriment between sexual organ and nutritive organ. The remarkable vegetative development of the nutritive organ was considered to have important correlation with the fruit-bearing. (Suge, 1952).

Micro- and megasporogenesis, as well as male and female gametogenesis of the genus Agapanthus, were first reported by Zhang et al. (2010). The anther wall, the development of which has a dicotyledonous type, consists of four layers: the epidermis, endothecium, one or two middle layers and the secretory tapetum. Fibrous thickenings develop in the endothecium during shedding. Sequential cytokinesis during microsporogenesis leads to a decussate tetrad of microspores. Ellipsoid pollen grains are 2-celled when the anthers disintegrate, with a mononucleate extending to the polar region. The ovary is superior and trilocular, with an axial placenta. The ovules are anatropic, and tenuinucellate. The archesporial cell under the epidermis of the nucellus functions directly as a megasporocyte (Zhang et al., 2010)

To understand the molecular mechanisms of flower initiation in A. praecox ssp. orientalis comprehensive transcriptomic and proteomic analyzes were made. Samples of stem tops were collected at three different points in time, including vegetative, induced, and reproductive periods. A large number of genes and proteins were regulated during the induced and reproductive stages. Their expression profiles demonstrate that carbohydrate metabolism provides the basis for floral initiation in Agapanthus (Zhang et al., 2013).

New features of the anatomical structure of the flower A. africanus and $A$. praecox, which we found, are the presence of three-bundle dorsal carpel bundles in $A$. africanus and single-bundle in A. praecox, the presence of a ventral complex that is reorganized into paired ventral vascular bundle, the presence of a high ovary base and the ovary roof, the presence of synascidiate, symplicate and a hemisymplicate gynoecium structural zones. Also, the height of the ovary zones in the studied species and the length of septal nectaries are very different.

\section{Conclusion}

The new data help deepen the knowledge about the micromorphological and anatomical features of the A. africanus and A. praecox flowers, in particular, the anatomical structure of tepals, gynoecium vertical zonality and vasculature of the flower as a whole were studied. The ovary revealed features of the early stages of fetal morphogenesis, as evidenced by triple dorsal bundles of carpels and long septal nectaries. Since the ovary is a structural basis of the fruit, histological ovary wall differentiation displays the specifics of further morphogenesis of the fruit. Septal nectaries in the $A$. africanus and $A$. praecox flowers occupy two-thirds of the length of the ovary and open at the base of the style. Nectary tissue surrounds the septal nectary slit, except for the bundles. All cells are located perpendicular to the surface of the nectary in the form of a fence, they are about 2 8 times longer than wider, often with more or less protruding outer walls, sometimes secondarily separated by transverse walls. The features of micromorphology and vascular anatomy obtained during the study will be further used in the taxonomy by morphological features for the family Amaryllidaceae.

\section{References}

Angiosperm Phylogeny Group (2003). An update of the Angiosperm Phylogeny Group classification for the orders and families of flowering plants: APG II. Botanical Journal of the Linnean Society, 141(4), 399-436.

Angiosperm Phylogeny Group (2009). An update of the Angiosperm Phylogeny Group classification for the orders and families of flowering plants: APG III Botanical Journal of the Linnean Society, 161(2), 105-121.

Barykina, R. P., Veselova, T. D., Deviatov, A. G., Djalilova, H. H., Iljina, G. M., \& Chubatova, N. V. (2004). Spravochnik po botanicheskoy mikrotehnike. Osnovy i metody [Handbook of botanical microtechniques]. Izdatelstvo Moskovskogo Universiteta, Moscow (in Russian).

Baskaran, P., \& Staden, J. (2013). Van Rapid in vitro micropropagation of Agapanthus praecox. South African Journal of Botany, 86, 46-50.

Baskaran, P., Chukwujekwu, J. C., Amoo, S. O., \& Staden, J. V. (2014). Anticholinesterase and mutagenic evaluation of in vitro-regenerated Agapanthus praecox grown ex vitro. In Vitro Cellular and Developmental Biology-Plant, 50, 271-275. 
Chase, M. W., Christenhusz, M. J. M., Fay, M. F., Byng, J. W., Judd, W. S., Soltis, D. E., Mabberley, D. J., Sennikov, A. N., Soltis, P. S., \& Stevens, P. F. (2016). The Angiosperm Phylogeny Group. An update of the angiosperm phylogeny group classification for the orders and families of flowering plants APG IV. Botanical Journal of the Linnean Society, 181, 1-20.

Chase, M. W., Reveal, J. L., \& Fay, M. F. (2009). A subfamilial classification for the expanded asparagalean families Amaryllidaceae, Asparagaceae and Xanthorrhoeaceae. Botanical Journal of the Linnean Society, 161(2), 132-136.

Cronquist, A. (1981). An integrated system of classification of flowering plants. New York Botanical Garden, Columbia University Press, New York.

Dahlgren, R. M. T., Clifford, H. T., \& Yeo, P. F. (1985). The families of the monocotyledons. Springer-Verlag, Berlin, Heidelberg, New York, Tokyo.

Daumann, E. (1970). Das Blütennektarium der Monocotyledonen unter besonderer Berücksichtigung seiner systematischen und phylogenetischen. Bedeutung Feddes Repertorium, 80, 463-590.

Dawson, M., Bodley, E., Stanley, R., Duncalf, I., \& Morgan, E. (2018). Assessing fertility in horticultural selections of Agapanthus. Acta Horticulturae, 1212, 41-62.

Duncan, G. (2004). 504. Agapanthus africanus subsp. walshii. Curtis's Botanical Magazine, 21, 205-214.

Fay, M. F., \& Chase, M. W. (1996). Resurrection of Themidaceae for the Brodiaea alliance, and recircumscription of Alliaceae, Amaryllidaceae, and Agapanthoideae. Taxon, 45(3), 441-451.

Fishchuk, O., Odintsova, A., \& Sulborska, A. (2014). Gynoecium structure in Dracaena fragrans (L.) Ker Gawl., Sansevieria parva N. E. Brown and Sansevieria trifasciata Prain (Asparagaceae) with septal emphasis on the structure of the septal nectary. Acta Agrobotanica, 66(4), 55-64.

Fogaça, L. A., Pedrotti, E. L., \& Alves, A. C. (2016). Micropropagation of Agapanthus umbellatus var. minor by using two systems of multiplication. Semina: Ciencias Agrarias, 37(5), 29232931.

Gómora-Hernández, J. C., Serment-Guerrero, J. H., Carreño-de-León, M. C., \& Flores-Alamo, N. (2019). Voltage production in a plant-microbial fuel cell using Agapanthus africanus. Revista Mexicana de Ingeniería Qulíp(riç,227-237.

Gören Sağlam, N., Aydın, N., Çă̆, S., \& Cevahir-öz, G. (2010). Flower development and senescence-related changes in Agapanthus africanus (Aliaceae). European Journal of Biology, 68(1), 55-59.

Leinfellner, W. (1950). Der Bauplan des Syncarpen Gynoeceums. Oesterreichische. Botanische Zeitschrift, 97, 403-436.

Meerow, A. W., \& Snijman, D. A. (1998). Amaryllidaceae. In: Kubitzki, K., Huber, H., Rudall, P. J., Stevens, P. S., \& Studzel, T. (Ed.). The families and genera of vascular plants. III. Flowering plants: Monocotyledons: Lilianae (except Orchidaceae). Springer, Berlin. Pp. 83-110.

Odintsova, A. (2013). Dva osnovnykh typy septalnykh nektarnykiv odnodol'nykh [Two main types of septal nectaries in monocotyledons]. Visnyk Lvivskogo Universytetu, Seriya Biologichna, 61, 41-50 (in Ukrainian).

Odintsova, A., \& Fishchuk, O. (2017). The flower morphology in three Convallariaceae species with various attractive traits. Acta Agrobotanica, 70(1), 17051719.

Pires, J. C., Maureira, I. J., Givnish, T. J., Sytsma, K. J., Seberg, O., Petersen, G., Davis, J. I., Stevenson, D. W., Rudall, P. J., Fay, M. F., \& Chase, M. W. (2006).
Phylogeny, genome size, and chromosome evolution of Asparagales. Aliso, 22, 287-304.

Ren, L., Deng, S., Chu, Y., Zhang, Y., Zhao, H., Chen, H., \& Zhang, D. (2020). Single-wall carbon nanotubes improve cell survival rate and reduce oxidative injury in cryopreservation of Agapanthus praecox embryogenic callus. Plant Methods, 16, 130.

Savchenko, T., Whiting, P., Sarker, S. D., \& Dinan., L., (1997). Phytoecdysteroids in the genus Agapanthus (Alliaceae). Biochemical Systematics and Ecology, 25(7), 623-629.

Seberg, O., Petersen, G., Davis, J. I., Pires, J. C., Stevenson, D. W., Chase, M. W., Fay, M. F., Devey, D. S., Jørgensen, T., Sytsma, K. J., \& Pillon, Y. (2012). Phylogeny of the Asparagales based on three plastid and two mitochondrial genes. American Journal of Botany, 99(5), 875-889.

Sharaibim, O., \& Afolayan, A. J. (2017). Micromorphological characterization of the leaf and rhizome of Agapanthus praecox subsp. praecox Willd. (Amaryllidaceae). Journal of Botany, 2017, 3075638.

Sharma, A. K., \& Mukhopadhyay, S. (1963). Chromosome study in Agapanthus and the phylogeny of its species. Caryologia, 16(1), 127-137.

Singh, D. N., Verma, N., Raghuwanshi, S., Shukla, P. K., \& Kulshreshtha, D. K. (2008). Antifungal activity of Agapanthus africanus extractives. Fitoterapia, 79(4), 298-300.

Skrypec, K., \& Odintsova, A. (2020). Morphogenesis of fruits in Gladiolus imbricatus and Iris sibirica (Iridaceae). Ukrainian Botanical Journal, 77(3), 210-224.

Suge, H. (1952). Studies on the flower breeding. I. Pollen development and fertility in Agapanthus umbellatus L. Her. Japanese Journal of Breeding, 2(2), 93-96.

Takhtajan, А. (2009). Flowering plants. 2nd ed. Springer, города?.

The Angiosperm Phylogeny Group (1998). An ordinal classification for the families of flowering plants. Annals of the Missouri Botanical Garden, 85(4), 531-553.

Yue, J., Zhang, D., Ren, L., \& Shen, X. (2016). Gibberellin and auxin signals control scape cell elongation and proliferation in Agapanthus praecox ssp. orientalis. Journal of Plant Biology, 59, 358-368.

Zhang, D., Ren, L., Shen, X., \& Zhuo, L. (2011). Fertilization and embryogeny in Agapanthus praecox ssp. orientalis (Leighton) Leighton. Plant Systematics and Evolution, 293, 25-30.

Zhang, D., Ren, L., Yue, J., Wang, L., Zhuo, L., \& Shen, X. (2013). A comprehensive analysis of flowering transition in Agapanthus praecox ssp. orientalis (Leighton) Leighton by using transcriptomic and proteomic techniques. Journal of Proteomics, 80, 1-25.

Zhang, D., Shen, X., \& Zhuo, L. (2011). Flower development and anatomy of Agapanthus praecox ssp. orientalis (Leighton) Leighton, Agricultural Sciences in China, 10(9), 1365-1373.

Zhang, D., Yang, T., \& Ren, L. (2021). Y2SK2- and SK3-type dehydrins from Agapanthus praecox act as protectants to improve plant cell viability during cryopreservation. Plant Cell Tissue Organ Culture, 144, 271-279.

Zhang, D., Zhuo, L., \& Shen, X. (2010). Sporogenesis and gametogenesis in Agapanthus praecox Willd. orientalis (Leighton) Leighton and their systematic implications. Plant Systematics and Evolution, 288, 1-11. 